\title{
The feedback between a tourism model and urban planning in La Manga, a mass tourist destination on the Spanish coast
}

\author{
S. García-Ayllón ${ }^{1}$ \& J. L. Miralles ${ }^{2}$ \\ ${ }^{1}$ Technical University of Cartagena, Spain \\ ${ }^{2}$ Polytechnic University of Valencia, Spain
}

\begin{abstract}
The urbanization process that shapes the current Mediterranean coast started in Spain with mass tourism, encouraged by the National Law of Tourist Interest Areas in 1963 as a strategic investment. Fifty years after its implementation, it is necessary to conduct a retrospective analysis of the results, for the evaluation of the goals set in the 60s. The evolution of the economic, political and legal parameters show certain deviations from the initial forecasts of many urban plans carried out in coastal places created from scratch.

The case of La Manga del Mar Menor is certainly an enlightening example of the results that have been achieved on a mass tourist destination. La Manga, located in the coastal Region of Murcia (south-eastern Spain), is a destination of 250,000 holidaymakers in summer which was a desert dune in the $60 \mathrm{~s}$. The study of feedback between a tourist model and urban planning reveals the problems of a tourist product to maintain its attractiveness in the long term. The short-term benefit of second homes versus hotels, the cost of maintaining the locations with high seasonality in demand or the target customer in a tourist destination are elements heavily influenced by urban planning in coastal cities. In this paper, all these elements will be distributed to either side of the balance, in order to evaluate the validity of the La Manga model.
\end{abstract}

Keywords: tourism strategies, urban planning, La Manga, Mar Menor, National Law of Tourist Interest Areas. 


\section{Introduction: La Manga del Mar Menor and Spanish tourism policy}

La Manga del Mar Menor, is now the main tourist attraction of Murcia, a coastal region in southeastern Spain. These ancient dunes hosts during the summer months more than 250,000 tourists attracted by the uniqueness of enjoying beaches washed by two seas: the Mar Menor to the west and the Mediterranean Sea to the east (Fig. 1).

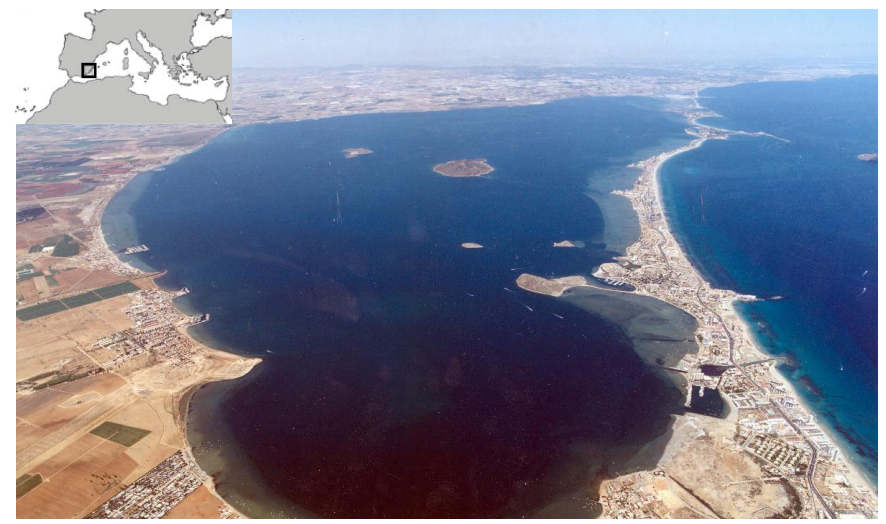

Figure 1: La Manga view from the south, between the Mar Menor (left) and the Mediterranean (right). Source: Atlas of Murcia.

The project for La Manga arises in the 60s as part of development plans that enhance tourism as the main economic activity in Spain. The National Law of Tourist Interest Areas and Centres creates in 1963, out of nowhere, many coastal tourist resorts such as La Manga. This plan is undertaken thanks to the substantial public funding that granted interest-free loans to private promoters for developing urban plans aimed at quality tourism of sun and beach in parts of Spain without tourist activity [1].

The results at the macroeconomic level for the country thanks to this policy shift towards tourism have been unquestionable. Tourism has grown from a residual sector until becoming the main source of income of Spain (Fig. 2). However, the results obtained in different resorts on the Spanish coast have been very heterogeneous. The case of La Manga is a very illustrative example of how wrong urban planning decisions can lead to premature obsolescence of a tourist destination as a product market.

\section{A successful tourism project initially}

During the making of La Manga as a tourist destination, businessman Tomás Maestre received in the $60 \mathrm{~s} 11,000$ million pesetas to develop a dune ridge nearly $20 \mathrm{~km}$ in length and make it a world-class tourist resort that houses up to 
60,000 visitors [2]. The business model was simple and Tomás Maestre based it on an urban masterplan developed in different phases and oriented to foreign and domestic customers with high purchasing power (Fig. 3).

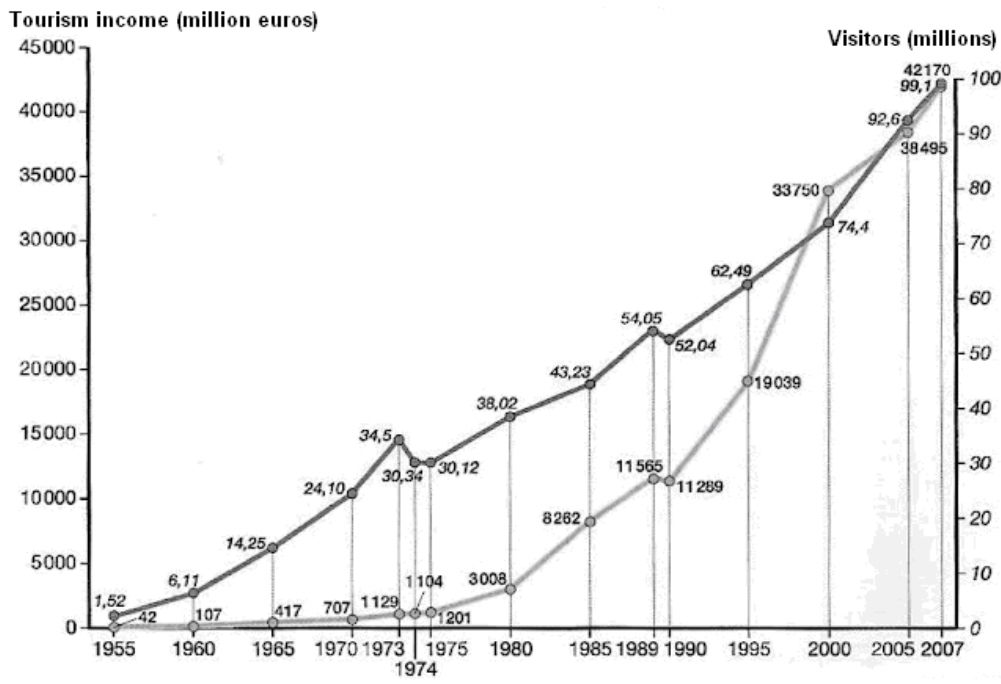

Figure 2: $\quad$ Evolution of the number of visitors (dark) and income (light) for tourism in Spain between 1955 and 2007. Source: [1, 2].

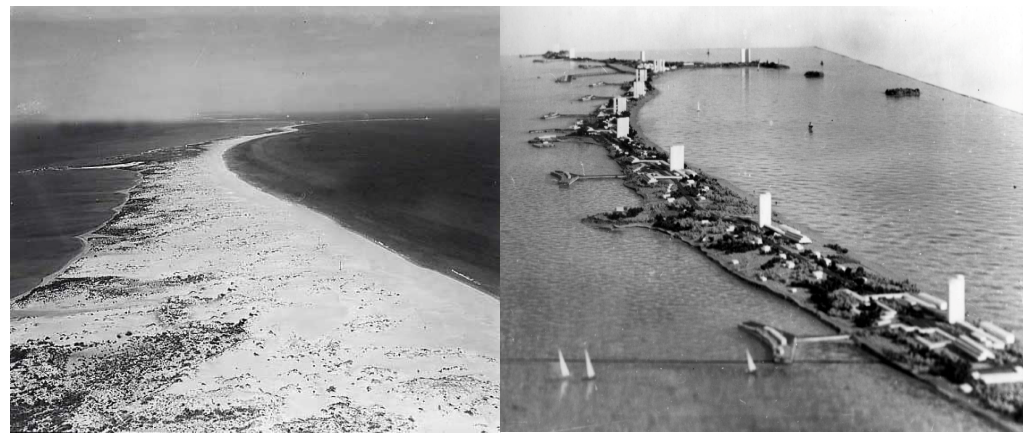

Figure 3: $\quad$ La Manga in 1956 (left) and model of the tourist project of Tomas Maestre in 1961 (right). Source: [2].

With state funding the development works of La Manga (roads, electricity, water, etc.) are undertaken and major facilities (marinas, casinos and hotels) are constructed. Revenues come from the management of hotels and sale of plots for large houses or second homes apartment buildings (Fig. 4). La Manga soon turns into an international-class destination, get great benefits that serve to further 
the development works and create new facilities that make it grow rapidly. The success of La Manga attracts VIPs and tourists with high purchasing power worldwide, which provide luxurious mansions on its beaches (Fig. 5).

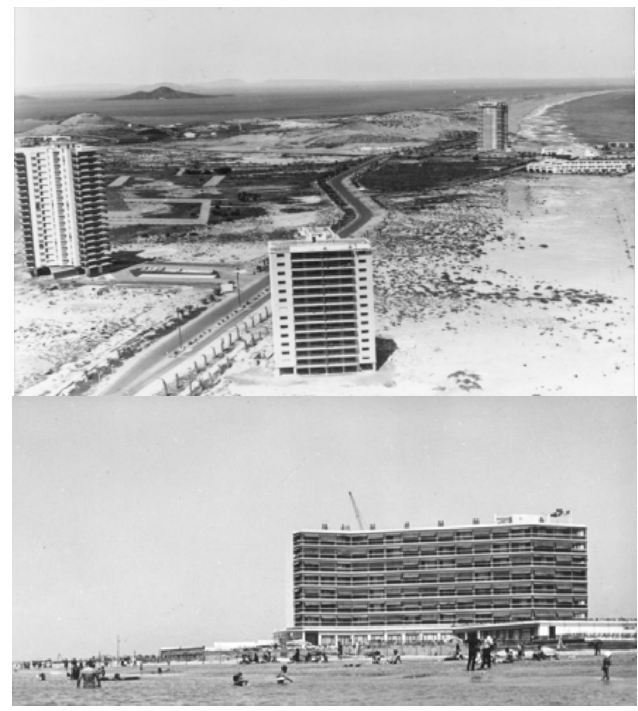

Figure 4: Infrastructure works and buildings in La Manga in 60s (2nd homes, left and hotel in right). Source: [2].

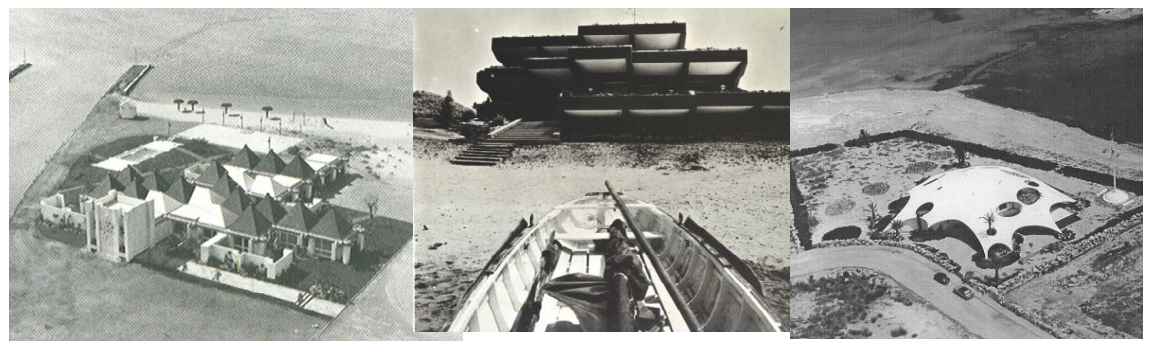

Figure 5: Luxury 2nd homes in La Manga. Source: [2].

\section{Oil crisis and the changing model of tourism in La Manga}

Certainly a point of inflection in the urbanization process of La Manga was the 1973 oil crisis, which hit all developed countries including (albeit with some delay), Spain [3]. The effects of the crisis were felt at all levels in the case of La Manga. On the one hand, the financial crisis ended soft loans provided by the government for the execution of the works, which now had to be financed by market conditions and with higher energy costs. On the other hand, the global economic crisis caused a sharp drop in demand for hotel occupancy and plot sales [3]. 
Crisis and the difficulty of access to finance forced the promoter Tomás Maestre to continue works paying multiple contractors with plots designed for housing and hotels. Thus, the tourism project of La Manga until then governed by a single masterplan of a promoter, becomes many small real estate projects that aim to make money in the short term with maximum building houses on the plots.

This causes a change in business model and the tourism project. Small developers do not want to manage hotels or sell plots to build single family homes, but to build apartment buildings for second homes, with the maximum number of dwellings (often illegally or exploiting loopholes). Works that were started in the first ten kilometres of La Manga (half length) are continued, but under these new criteria from the mid-70s. This new tourism planning leads to a new urban landscape in La Manga.

The original masterplan had built in 1975 hotels and facilities in the first half of La Manga. The original tourism project planned that most of the apartments were put on the market once the hotels had consolidated La Manga as an international destination. Thus, foreign customers who already knew La Manga for coming to their hotels at different times might feel interested in acquiring home ownership. The unexpected situation caused two major changes in the development process of La Manga: on one hand, second residence apartments multiplied in the first half (south of La Manga area), and on the other hand, most hotels and equipment planned in the second half (north area) were not executed, whose plots were finally destined to second homes (Fig. 6).

This situation had important consequences in La Manga as a town and as a tourism product. First, the visitor population of the new city grew by leaps and bounds from the 70 s.

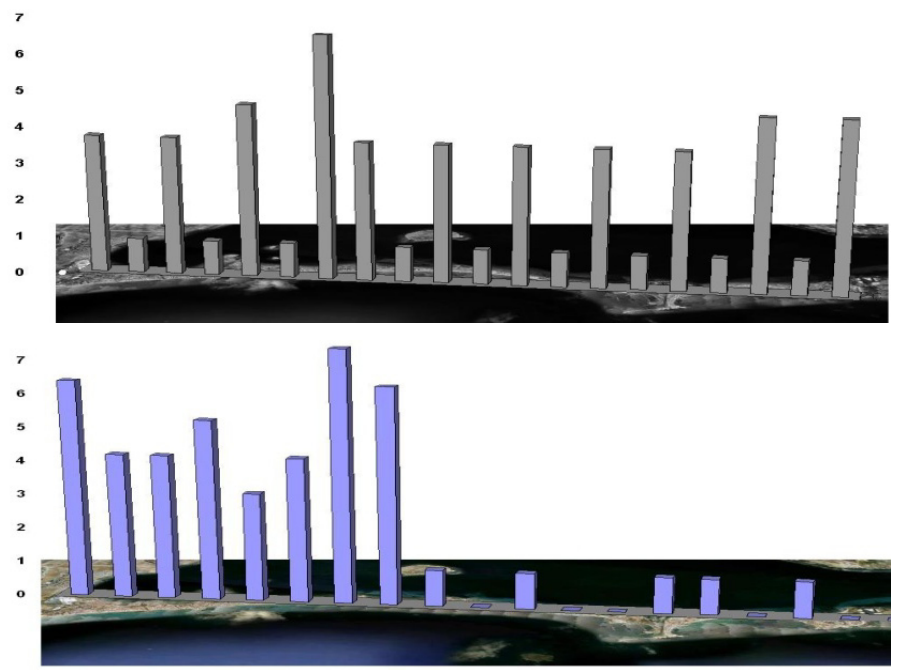

Figure 6: Geographical distribution of hotels planned in the original project (top) and final distribution today (below). Source: [2]. 
In 1984, the supply of hotel accommodation and second homes already exceeded the 60,000 total seats which provided the whole starting project. In 1988 reached nearly 100,000 and more than 200,000 in 2005. Nevertheless, if we analyze the figures in detail we can see how the real growth was occurring only in second homes, which multiplied exponentially. The hotel accommodation began to grow more slowly from 1975 to stagnate in the 80s (Table 1).

Table 1: Evolution of hotel beds vs. 2nd homes in La Manga. Source: modified from [3].

\begin{tabular}{|c|c|c|c|c|c|c|c|}
\hline Year & $\mathbf{2}^{\text {nd }}$ homes & Hotel beds & TOTAL & Year & $\mathbf{2}^{\text {nd }}$ homes & Hotel beds & TOTAL \\
\hline $\mathbf{1 9 6 5}$ & 820 & 0 & 820 & $\mathbf{1 9 7 7}$ & 40,727 & 1,586 & 42,313 \\
\hline $\mathbf{1 9 6 6}$ & 1,528 & 217 & 1,745 & $\mathbf{1 9 7 8}$ & 42,272 & 2,521 & 44,793 \\
\hline $\mathbf{1 9 6 7}$ & 3,193 & 563 & 3,756 & $\mathbf{1 9 8 4}$ & 62,110 & 2,521 & 64,631 \\
\hline $\mathbf{1 9 7 2}$ & 18,228 & 563 & 18,791 & $\mathbf{1 9 8 8}$ & 97,004 & 2,577 & 99,576 \\
\hline $\mathbf{1 9 7 3}$ & 23,180 & 1,586 & 24,766 & $\mathbf{2 0 0 5}$ & 202,177 & 2,965 & 205,142 \\
\hline $\mathbf{\%}$ & $\mathbf{9 3 , 5} \%$ & $\mathbf{6 , 5} \%$ & $\mathbf{1 0 0} \%$ & $\mathbf{\%}$ & $\mathbf{9 8 , 6 \%}$ & $\mathbf{1 , 4 \%}$ & $\mathbf{1 0 0} \%$ \\
\hline
\end{tabular}

These changes led to a significant metamorphosis in La Manga as a tourism product. The new business model aimed at selling more accommodation but more affordable, and based on the sale of second homes. These ones produced more rapid economic returns compared to hotels, inputting a new customer profile. This new costumer was a more local tourist, usually national but less purchasing power, and wanted to buy a house for the summer. This new lower added value client cohabited between the late 70 s and early $80 \mathrm{~s}$, with the former one, which was foreign or domestic but with high purchasing power. This cohabitation did not last long, "expelling" finally the overcrowding of local client in La Manga the foreign customer (Fig. 7).
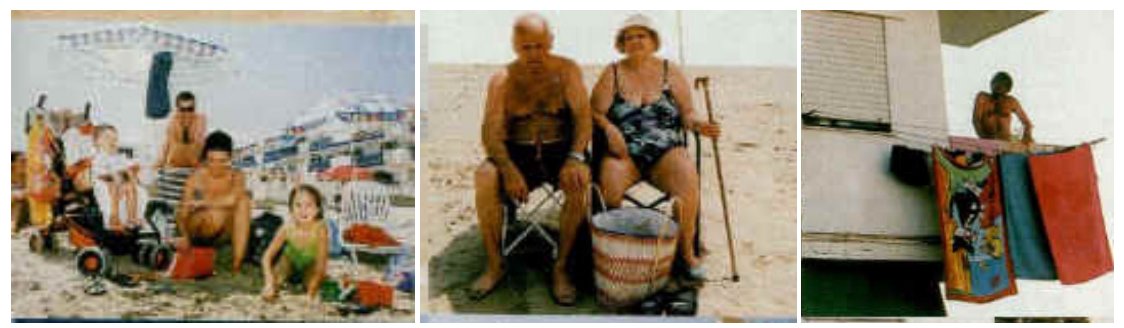

Figure 7: New customer type La Manga from the 80s. Source: Blanco y Negro Magazine, No. 24, 2001. 
This "mutation" in the target customer was soon reflected in the urban landscape of La Manga. Some equipment projects that began to be built in the $70 \mathrm{~s}$ in the north area, as the expansion of Casino Dos Mares, were never completed (in fact, the casino itself finally closed). Others like the shooting club were substituted by $2^{\text {nd }}$ home buildings (Fig. 8), because this new client did not consume that kind of product. In fact, it was a customer with little added value, since it was actually a tourist who consumed little since their substantial financial investment was made in the purchase of the second residence. To This question is now added another, which was the deepening of the seasonality in tourism demand, which was concentrated in the months of July, August and September, with a very tight supply generating thousands of empty homes the rest of the year as if it was a ghost town. This caused problems in services management (waste collection, police or street lighting) and a significant oversizing of infrastructure (roads, water systems, etc., Fig. 9).
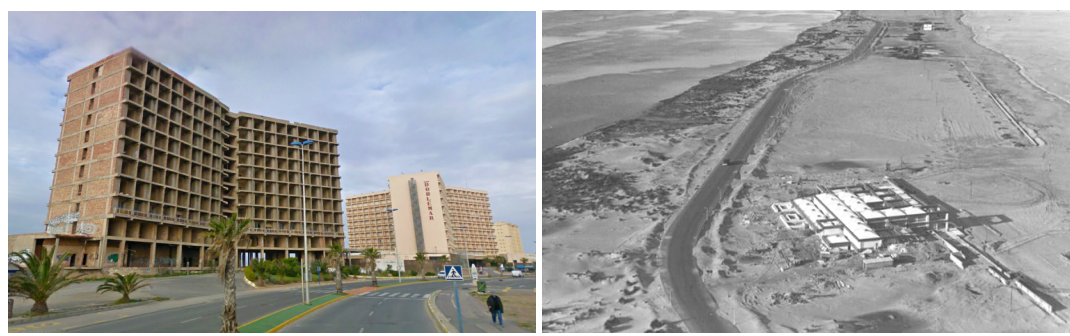

Figure 8: Abandonment of Casino Dos Mares (left) and disappeared shooting club (right). Source: Authors and archive VECOS promoter.

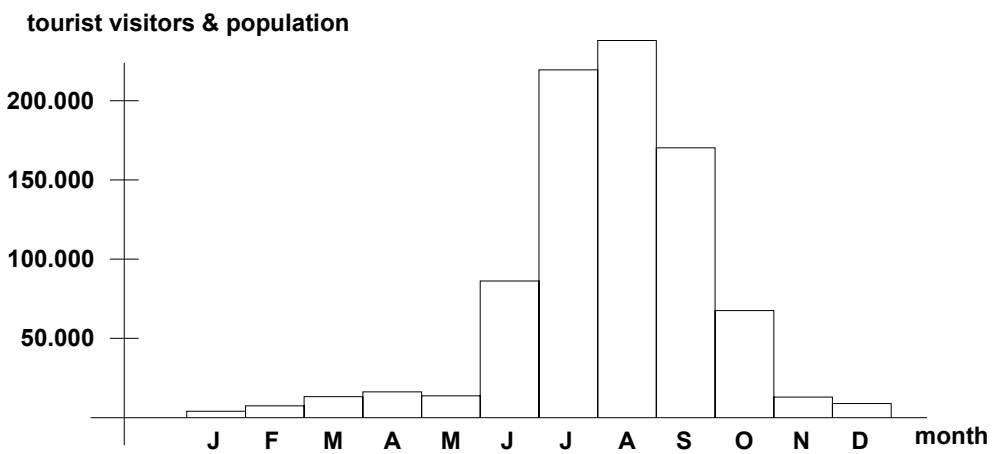

Figure 9: La Manga visitor's annual distribution in 2012. Source: [5]. 


\section{Current analysis of changing model consequences: feedback of urbanization and tourist model}

Inertia initiated in the mid-70s will be consolidated in the $80 \mathrm{~s}$. In the early $90 \mathrm{~s}$, the tourism model seems to be exhausted (Fig. 10). However, with the beginning in the mid-90s of the housing bubble (half of the homes built in Spain were located on the Mediterranean coast, see [6] and [7]), the sale of plots and apartments construction are not completely stopped.

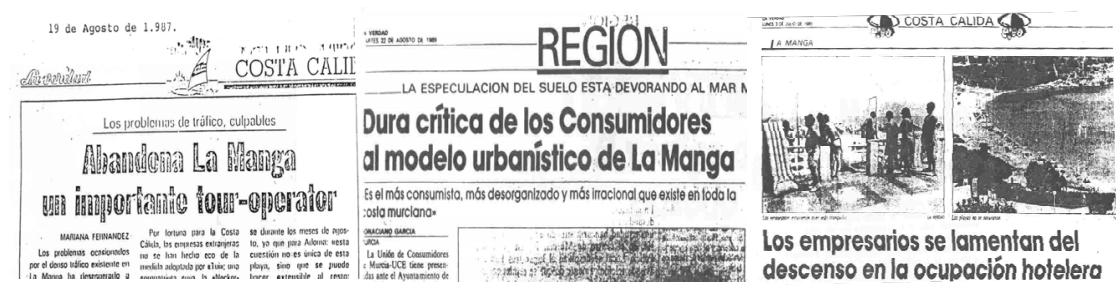

Figure 10: Criticism of the tourism model in La Manga in the late 80s. Source: La Verdad y La Opinión de Murcia journals, years 1987, 19881991.

Looking at La Manga as a tourism product market from the perspective of supply and demand for land, we can show the depletion of La Manga as a tourism product and its premature obsolescence as product market due to wrong planning policy implemented.

The tip of La Manga visitor population has grown to nearly 250,000 visitors in recent years (Fig. 11). However, this growth has not been uniform nor continuous, but reveals own deficiencies of La Manga as a tourism product. This tourist population remains constant these latter years despite the global economic crisis, because most of these tourists are $2^{\text {nd }}$ home owners.

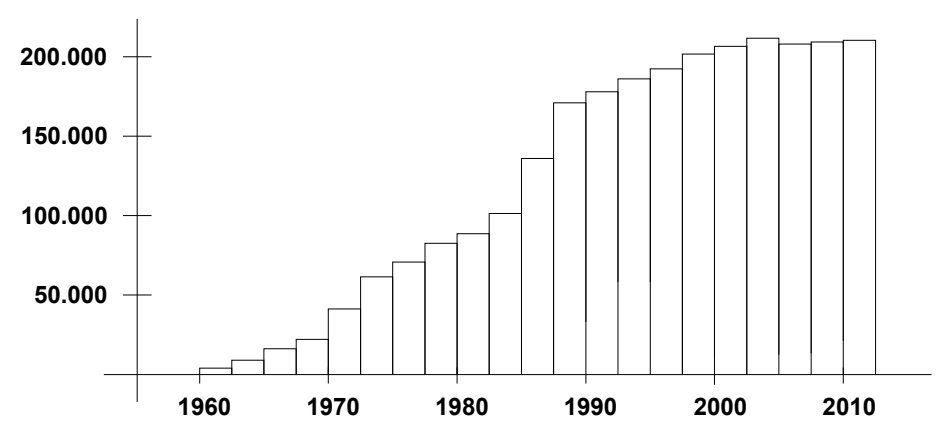

Figure 11: Evolution of peak tourist population in La Manga. Source: [2]. 
If we compare the first half of La Manga (south) and the second half (north) we notice a very different urban appearance. In the south, which was urbanized (and where hotels and facilities were built) before 1973, we found a clogged building environment (Fig. 12, left). Nevertheless, in the north, the urban builtup area has numerous voids (even in privileged surroundings of the beach) without any presence of hotels and equipment (Fig. 12, right). Looking at the graphs of house building intensity (directly linked to the sale thereof) we see continued growth of urban area until stagnation in the early 90s in both north and south half of La Manga. However, it should be stressed that this urban surface reaches $100 \%$ in the first one but does not exceed $66 \%$ in the second one (Fig. 13).
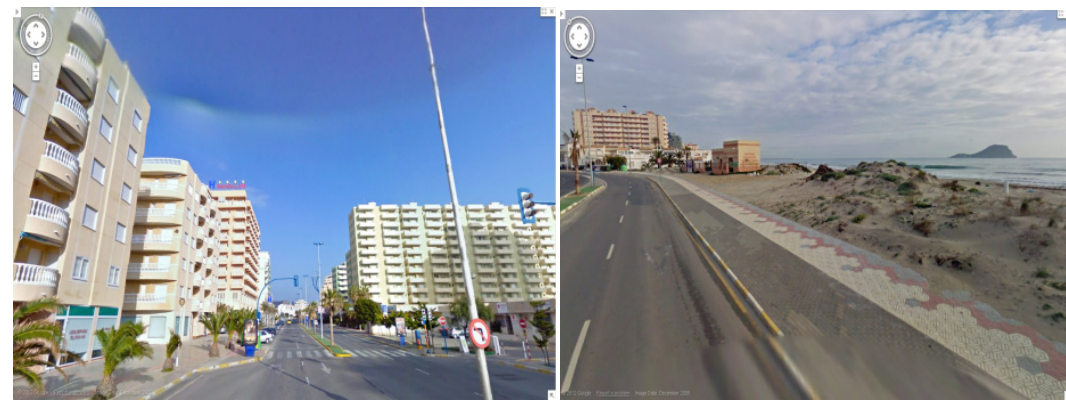

Figure 12: Southern half (left) and northern half (right). Source: authors.

The graphs analyzed show that La Manga clogging as a tourism product in the south (by overcrowding) contributed to a loss of value in the set of the tourist destination.
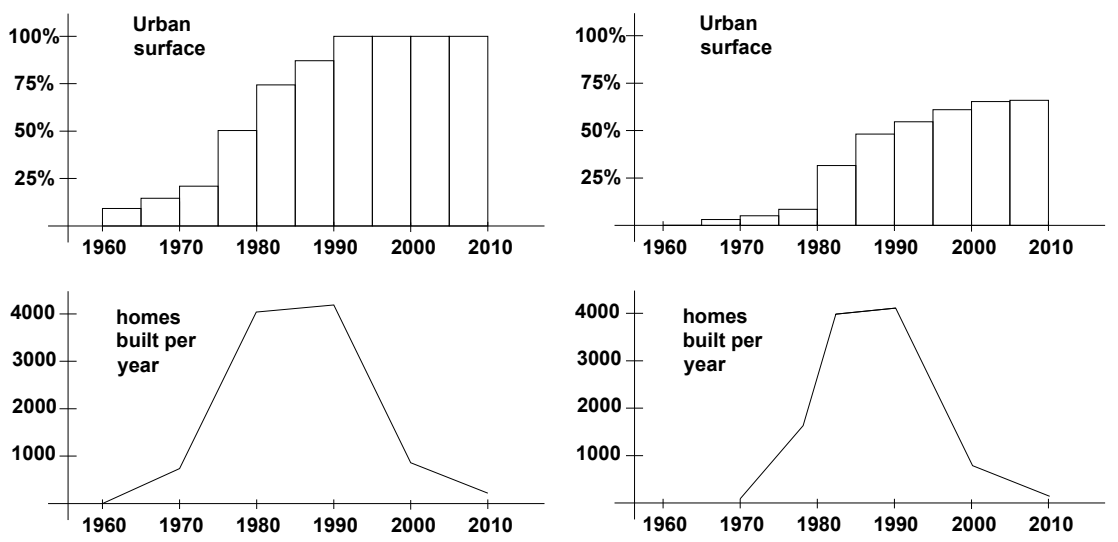

Figure 13: Evolution of artificial surface and build construction in south (left) and north (right) zone of La Manga. Origin: modified from [3]. 
This situation leads in the north to a fall in demand for plot sales and housing construction. If we translate this in terms of economic returns of tourism product generating an index of average expenditure per tourist in La Manga (updated over time in line with inflation), we can see how this tourist destination has grown from a destination with high added value to what is now called a "mature" destination (Fig. 14). Being this a consolidated basis, only by adding value with urban renewal projects, we can achieve to increase attractiveness [8].

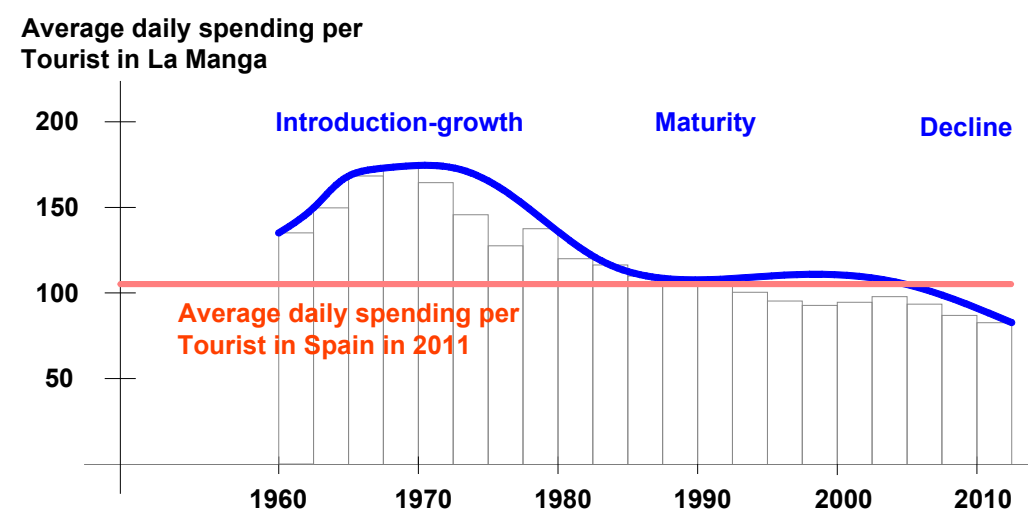

Figure 14: Life product model of La Manga as tourist market product. Source: modified from [3].

\section{Conclusions}

- There is a strong feedback between the urban model of La Manga and its profitability as a tourism product. The urbanization process developed after the oil crisis changed a successful product in the 70 s to a product currently with low value-added and major problems of seasonality demand.

- The wrong policy of favouring urban second homes versus hotel equipment produced a strong economic return in the short term, but contributed to overcrowding. This overcrowding "mutated" the type customer of La Manga, deteriorating profitability and long-term tourism product.

- It should be noted that the final model, based on a local and national tourism with low added value, seems paradoxically be quite resistant to the effects of the economic crisis gripping Spain since 2008.

- The solutions of urban problems in currently model are very complicated. No room to expand infrastructure and equipment or to introduce new ones. The changing of the model may be possible rethinking local situation by long time projects to improve the attractiveness [9] or introducing new cultural forms such as low carbon landscapes [10]. 


\section{References}

[1] Galiana L. \& Barrado D. Los centros de interés turístico nacional y el despegue del turismo de masas en España. Investigaciones Geográficas $\mathrm{n}^{\mathrm{o}}$ 39, pp. 73-93. ISSN: 0213-4691, 2006.

[2] García-Ayllón S. En los procesos de urbanización del mediterráneo: el caso La Manga. PhD thesis, Polytechnic University of Valencia, 2013.

[3] Miralles i Garcia, J.L., García-Ayllón S. The economic sustainability in urban planning: case La Manga. WIT Transactions on Ecology and The Environment, Vol. 173, WIT Press: Southampton, pp. 379-389, 2013.

[4] López-Morell M., Pedreño A. y Baños P. "Génesis y trayectorias del desarrollo turístico del entorno del Mar Menor". VIII Congreso de la Asociación Española de Historia Económica, 2006.

[5] Statistics of 2012 in www.murciaturistica.es. Region of Murcia (Spain).

[6] Rullán, O. La regulación del crecimiento urbanístico en el litoral mediterráneo español. Ciudad y Territorio $\mathrm{n}^{\mathrm{o}} 168 . \mathrm{M}^{\mathrm{o}}$ de Fomento, 2011.

[7] Miralles i Garcia, J.L. Real estate crisis and sustainability in Spain. WIT Transactions on Ecology and the Environment, Vol. 150, WIT Press: Southampton, pp. 123-133, 2011.

[8] Miralles J.L., Díaz S. \& Altur V.J. Environmental impact on the Mediterranean Spanish coast produced by the latest process of urban development. WIT Transactions on Ecology and the Environment, Vol. 155, WIT Press: Southampton, pp. 379-389, 2012.

[9] Scott, A. \& Ben-Joseph, E. Renewtown. Adaptative urbanism and the low carbon community. Routledge: New York and Oxon, 2012.

[10] Fraker, H. The hidden potential of sustainable neighbourhoods. Lessons for Low-Carbon Communities. Island Press: Washington, Covelo, London, 2013. 